\title{
APLIKASI AUGMENTED REALITY (AR) SEBAGAI MEDIA EDUKASI PENGENALAN BENTUK DAN BAGIAN PESAWAT BERBASIS ANDROID
}

\author{
Ayub Wimatra ${ }^{1}$, Sunardi $^{1}$, Rizaldy Khair ${ }^{2}$, Iswandi Idris ${ }^{* 2}$, Asri Santosa ${ }^{2}$ \\ ${ }^{1}$ Politeknik Penerbangan Medan \\ J1. Penerbangan No. 85, Sempakata, Kec. Medan Selayang, Medan \\ ${ }^{2}$ Politeknik LP3I Medan \\ J1. Sei Serayu No. 48 D, Medan \\ *Corresponding author E-mail : iswandi.idriseplm.ac.id
}

\begin{abstract}
Augmented Reality is a merger between two worlds, namely the virtual world to the real world, in other words, we can display objects in the virtual world into the real world. Augmented Reality has many opportunities to continue to be developed in any field. The Augmented Reality method also has the advantage of an interactive side because the makers to display certain videos that are directed to the webcam. Making an interactive learning media application using augmented reality technology will be applied to Android-based smartphones and is designed as a learning medium for cadets and prospective cadets of ATKP Medan to the general public. In this application, there are 3D objects in the shape of the plane and its parts created using the 3Dsmax and Blender applications, with Unity as the game engine and Vuforia as the library. The way to use it is by pointing the smartphone camera at the markers that have been provided. Then on the smartphone screen, an object will appear 3D aircraft and the inside. The making of this application will help increase the understanding and participation of the general public as well as the Medan ATKP cadets in learning to recognize the shapes and parts of the aircraft. The results of testing the introduction of an aircraft application can run on a variety of Android mobile devices. The normal distance that can be detected by the camera is $6 \mathrm{~cm}$ to $4 \mathrm{~m}$ with a marker size of $20 \times 22 \mathrm{~cm}$. The slope that can be detected normally between $20^{\circ}-90^{\circ}$. Based on the percentage of markers that are blocked can run between $0-87 \%$. Based on the results of the questionnaire, the material contained in the aircraft form and part recognition application using Android-based Augmented Reality is suitable for introducing aircraft shapes and parts to field ATKP cadets to the general public. There are still many shortcomings that can be developed, such as increasing 3D plane objects and making better animations, so that applications are more interesting, interactive, and easy to understand.
\end{abstract}

Keywords - Augmented Reality, Android, Unity, Vuforia, 3D, Blender

\begin{abstract}
Augmented Reality merupakan penggabungan antara dua dunia, yaitu dunia maya ke dunia nyata, dalam kata lain benda dalam dunia maya dapat kita tampilkan ke dunia nyata. Augmented Reality memiliki banyak peluang untuk terus dikembangkan dalam bidang apapun. Metode Augmented Reality juga memiliki kelebihan dari sisi interaktif karena pembuat untuk menampilkan video tertentu yang diarahkan ke webcam. Pembuatan aplikasi media pembelajaran interaktif menggunakan teknologi augmented reality ini akan diterapkan pada smartphone berbasis Android dan didesain sebagai media pembelajaran bagi taruna maupun calon taruna ATKP Medan hingga masyarakat umum. Di dalam aplikasi ini terdapat objek 3D bentuk pesawat dan bagianbagiannya yang dibuat dengan menggunakan aplikasi 3Dsmax dan Blender, dengan Unity sebagai game engine dan Vuforia sebagai library. Cara penggunaanya adalah dengan mengarahkan kamera smartphone pada marker atau penanda yang telah tersedia. Kemudian dilayar smartphone akan muncul objek 3D Pesawat serta bagian sisi dalamnya. Pembuatan aplikasi ini akan membantu meningkatkan pemahaman dan partisipasi masyarakat umum maupun taruna ATKP Medan dalam belajar mengenal bentuk dan bagian dalam pesawat. Hasil dari pengujian aplikasi Pengenalan pesawat terbang dapat berjalan pada berbagai perangkat mobile Android. Jarak normal yang dapat terdeteksi oleh kamera adalah $6 \mathrm{~cm}$ sampai $4 \mathrm{~m}$ dengan ukuran marker $20 \mathrm{x} 22 \mathrm{~cm}$. Kemiringan yang dapat terdeteksi dengan normal antara $20^{\circ}-90^{\circ}$. Berdasarkan prosentase marker yang terhalang dapat berjalan antara $0-87 \%$. Berdasarkan hasil kuesioner materi yang terdapat pada aplikasi pengenalan bentuk dan bagian pesawat menggunakan Augmented Reality berbasis android ini cocok untuk mengenalkan bentuk dan bagian pesawat kepada taruna ATKP medan hingga masyarakat umum. Masih banyak kekurangan yang dapat dikembangkan, misalnya memperbanyak objek 3D pesawat dan membuat animasi yang lebih baik, agar aplikasi lebih menarik, interaktif, dan mudah dipahami.
\end{abstract}

Kata Kunci - Augmented Reality, Android, Unity, Vuforia, 3D, Blender 


\section{PENDAHULUAN}

Akademi Teknik dan Keselamatan Penerbangan (ATKP) Medan merupakan institusi pendidikan kedinasan dibawah Kementerian Perhubungan yang bergerak dalam bidang penerbangan memiliki empat program studi unggulan antara lain, Pemandu Lalu Lintas Udara, Teknik Listrik Bandara, Teknik Telekomunikasi dan Navigasi Udara, serta Teknik Pesawat Udara. Semakin majunya sistem komunikasi dan teknologi informasi pada masa sekarang ini, berdampak pada perubahan banyak sistem, salah satunya sistem pendekatan pembelajaran. Dengan demikian mengharuskan adanya transformasi dan inovasi dalam metode pembelajaran terdahulu (konvensional), dengan guru/dosen sebagai pemegang peranan utama dan ruangan kelas sebagai tempat pelaksanaannya yang kini telah banyak berubah. Sistem pendekatan pembelajaran telah berubah ke arah pembelajaran masa depan yang bisa juga disebut sebagai pembelajaran abad pengetahuan. Sistem ini yang membuat orang dapat belajar di mana saja tanpa batas waktu dan tempat serta dengan siapa saja. Selain dari sistem pembelajaran, media pembelajaran juga mengalami peningkatan kebutuhan dan beraneka ragam jenisnya. Media pembelajaran yang banyak digunakan saat ini hanya berupa buku teks dimana buku-buku teks tersebut memiliki beberapa kelemahan seperti: desain buku yang sering tidak sesuai dengan kurikulum sehingga mengakibatkan program pendidikan tidak tercapai, bahan ajar yang terkesan biasa dan kadaluarsa yang dikarenakan selang waktu penggunaan yang lama sehingga informasi yang ada sebagian tidak sesuai lagi dengan yang dihadapi oleh peserta didik, pelatihan dan tugas yang kurang memadai karena keterbatasan ukuran buku [1].

Maka dari itu dibutuhkan sebuah teknik pembelajaran yang sesuai sebagai saluran penyampaian pesan-pesan pendidikan agar pembelajaran yang didapatkan berjalan dengan baik

Berdasarkan pembahasan media pembelajaran tersebut, maka dari itu dibuatlah Aplikasi Augmented Reality (AR) Sebagai Media Edukasi Pengenalan Bentuk dan Bagian Pesawat Berbasis Android. Sistem ini akan sangat membantu dalam hal pengenalan bentuk dan bagian pesawat oleh taruna hingga masyarakat umum.

\section{Augmented Reality (AR)}

Augmented Reality adalah upaya untuk menggabungkan dunia nyata dan dunia virtual yang dibuat oleh komputer, sehingga batas antara keduanya menjadi lebih singkat. AR masih dalam masa pengembangan, namun banyak futuris dan peneliti mengharapkan agar dapat diaplikasikan pada tahun 2010-2020-an.
Benda-benda maya menampilkan informasi yang tidak dapat diterima oleh pengguna dengan inderanya sendiri. AR juga telah diaplikasikan dalam perangkatperangkat teknologi yang banyak digunakan orang pada umumnya, seperti pada telepon genggam. Sebagai contoh penerapan AR pada bidang pendidikan adalah AR yang digunakan pada suatu Sekolah Menengah Atas di Thailand, sebuah aplikasi AR yang merupakan media pembelajaran interaktif reaksi kimia berbasis desktop .

Arsitektur teknologi ini hampir sama pada teknologi pada umumnya, hanya saja letak perbedaannya ada pada input dan outputnya.

1. Input pada AR, proses input ini sistem mendeteksi sensor dari benda nyata. Seperti gambar, sensor getaran, lokasi hingga sensor gerakan.

2. Kamera/Alat penangkap sensor lainnya. Di sini sensor-sensor dari dunia nyata diterima dan dijadikan informasi yang nantinya akan diproses oleh sistem.

3. Prosessor. Di sinilah proses inti dari kera teknologi AR. Pada bagian ini, sistem akan memproses informasi yang masuk dan menemukan informasi apa yang akan di keluarkan.

4. Output. Output menampilkan informasi-informasi yang sudah ada di proses. Output dapat berupa monitor, layar ponsel dan sebagainya.

Tidak seperti Virtual Reality yang sepenuhnya menggantikan kenyataan, AR sekedar menambahkan atau melengkapi kenyataan. Keunggulan dari AR dibandingkan Virtual Reality adalah pengembangan yang lebih mudah dan tidak memerlukan banyak biaya. Sehingga AR merebak secara cepat di berbagai bidang yang bahkan belum dapat dijangkau oleh pendahulunya tersebut. Keunggulan lain yaitu dapat diimplementasikan secara luas dalam berbagai media. Sebagai aplikasi dalam sebuah smartphone, console game, dalam bingkisan sebuah produk, bahkan media cetak seperti buku, majalah dan koran [2]

\section{Vuforia}

Vuforia SDK adalah Software Development Kit berbasis AR yang menggunakan layar perangkat mobile sebagai "lensa ajaib" atau kaca untuk melihat kedalam dunia Augmented dimana dunia nyata dan virtual muncul berdampingan. Aplikasi ini membuat preview kamera secara langsung pada layar smartphone untuk mewakili pandangan dari dunia fisik. Objek 3D akan nampak secara langsung dilayar smartphone, sehingga akan terlihat Objek 3D berada di dalam dunia nyata, Vuforia SDK terdiri dari 2 komponen utama yaitu library QCAR dan target management sistem.

Vuforia dapat mendeteksi beberapa jensi target, target yang digunakan disini adalah Image targets, merupakan target yang bersifat image/gambar seperti 
photo, game boards, halaman majalah, cover buku, brosur serta gambar-gambar lainnya. Image tracking atau image target adalah metode pendeteksian dan pelacakan target berdasarkan gambar. Tidak seperti marker tradisional seperti kode matrix atau code $\mathrm{QR}$, image target Vuforia tidak membutuhkan garis hitam khusus dan daerah putih atau code untuk mengenalinya. Vuforia SDK mendeteksi dan melacak natural fitur yang ditemukan pada sebuah gambar dengan membandingkan pada gambar yang telah ditentukan didatabase. Setelah image target terdeteksi, maka Vuforia SDK akan melacak gambar asalkan terdapat bagian marker yang terlihat dikamera (Sugiarto, 2016).

\section{Camera}

Camera merupakan tools untuk mengambil informasi-informasi yang berada pada objek dunia nyata [1].

\section{Application Code}

Proses coding dalam mengolah informasiinformasi yang di dapat. Proses-proses itu meliputi Query dari target yang telah terdeteksi, Logic aplikasi dan Render graphic (Objek 3D) (Purwanto, 2016).

\section{Database}

Database dibuat secara online menggunakan Target Manager. Database terdiri dari dua tipe, database yang disimpan pada device dan database yang disimpan pada server (Cloud) (Speckmann, 2008).

\section{Android}

Pengertian Android dari sudut pandang pemrograman. Android merupakan subset perangkat lunak untuk perangkat mobile yang meliputi sistem operasi, middleware dan aplikasi inti yang di release oleh Google, sedangkan Android SDK (Software Development Kit) menyediakan tools dan API yang diperlukan untuk mengembangkan aplikasi pada platform Android dengan menggunakan bahasa pemrograman Java [3].

Beberapa fitur ungggulan yang terdapat dalam system operasi Android (Speckmann, 2008) adalah:

a. Kerangka aplikasi : memungkinkan penggunaan dan penghapusan komponen yang tersedia.

b. Dalvik mesin virtual : yang dioptimalkan untuk perangkat telepon seluler.

c. Grafik : grafik di 2D dan grafis 3D berdasarkan pustaka OpenGL.

d. SQLite : untuk penyimpanan data.

e. Mendukung media : audio, video dan berbagai format gambar (MPEG4, H.264, MP3, AAC, AMR, JPG, PNG, GIF).

\section{Unity}

Unity Game Engine merupakan software yang digunakan untuk membuat video game 3D atau konten yang interaktif lainnya seperti, visual arsitektur dan realtime 3D animasi (Speckmann, 2008).

\section{NGUI}

NGUI adalah plugin Unity yang dikhususkan untuk membuat UI sistem yang powerfull. Ditulis menggunakan bahasa pemrograman $\mathrm{C \#}$ dengan baris teks yang simpel dan minimalis. Banyak class yang ditulis dibawah 200 baris code. Untuk seorang programmer ini berarti akan lebih mudah ketika bekerja menggunakan peralatan untuk menambah fitur dari yang sudah ada. Untuk semua orang akan memiliki kinerja yang lebih baik dan lebih menyenangkan (Purwanto, 2016)

\section{METODE PENELITIAN}

Metode pengumpulan data

Pengumpulan data dengan menggunakan metode pengamatan/observasi serta wawancara dengan menyebarkan kuesioner yang telah ditentukan.

a. Pengamatan, dilakukan dengan melihat pelaporan kepada orang tua taruna tentang kegiatan sehari-hari, hingga perilaku taruna ATKP.

b. Wawancara, dilakukan terhadap taruna ATKP Medan, para dosen masyarakat umum yang ikut serta di dalam menggunakan aplikasi media pembelajaran ini.

Rancangan Penelitian

Analisis Kebutuhan

Tahap ini menganalisis kebutuhan apa saja yang akan diperlukan dalam pembuatan aplikasi Augmented Reality mulai dari konsep dan alur media, pemilihan materi yang layak dan sesuai dengan alat-alat yang dibutuhkan dalam pembuatan aplikasi ini. Sehingga nantinya aplikasi AR yang dibuat dapat dijadikan sebagai alternatif belajar untuk Taruna ATKP Medan dalam membantu memahami materi yang diajarkan oleh pengajar / dosen. Selain itu dikarenakan juga pesatnya perkembangan smartphone diharapkan dapat memberikan kemudahan akses kapanpun dan dimanapun bagi setiap orang untuk melakukan aktivitas yang berkaitan dengan pendidikan dan hiburan.

\section{Perancangan Aplikasi}

Data cockpit yang peneliti masukkan pada aplikasi ini adalah Altimeter, Attitude Indicator, Airspeed Indicator, Magnetic Compass, Heading Indicator, Turn Indicator, Vertical Speed Indicator, dan lain-lain. Setelah semua data didapat, peneliti membuat model 3D, membuat marker, dan menggabungkan hasil tersebut kedalam bentuk 
Augmented Reality yang berjalan pada sistem operasi Android.

1. Augmented Reality pada aplikasi ini dibuat menggunakan Software Unity 3D. Untuk membuat Augmented Reality menggunakan Unity diperlukan Vuforia SDK yang merupakan produk dari Qualcomm. Paket Vuforia SDK berisi library-library yang berguna agar aplikasi dapat mengenal gambar sebagai marker.

Langkah pertama untuk membuat AR ini adalah membuat sebuah marker. Gambar yang menjadi marker didesign menggunakan Paint. Marker dibuat dengan cara mengupload gambar marker yang sudah dibuat ke situs web https://developer.vuforia.com/. Untuk mengupload gambar di web tersebut, diharuskan melakukan registrasi. Setelah melakukan registrasi dan sign ini, masuk ke target manager kemudian klik Add Database, tulis nama database misalnya Anjing. Klik create untuk membuat database.

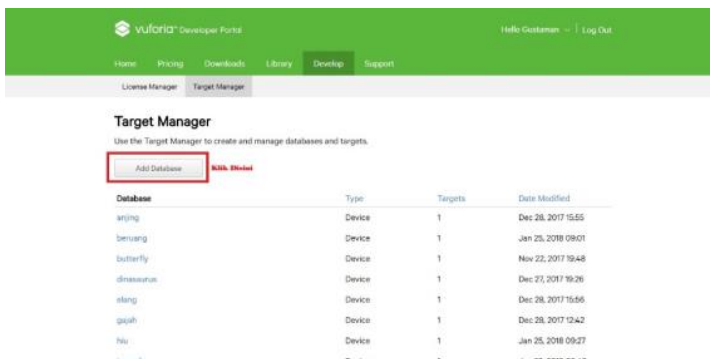

Gambar 1 Membuat database pada web vuforia

Setelah membuat database, upload gambar marker dengan cara klik add target, pilih single image, kemudian pilih gambar yang akan dijadikan marker, tentukan dimensi target lalu beri nama dan klik add.

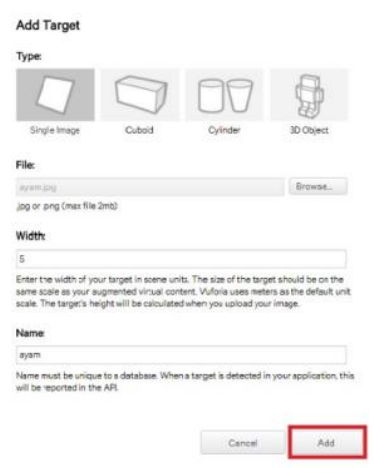

Gambar 2 Upload marker

Gambar yang telah berhasil diupload selanjutnya akan diolah oleh web dan juga diberi nilai. Semakin banyak bintang yang diberikan berarti semakin baik gambar tersebut untuk dijadikan marker.

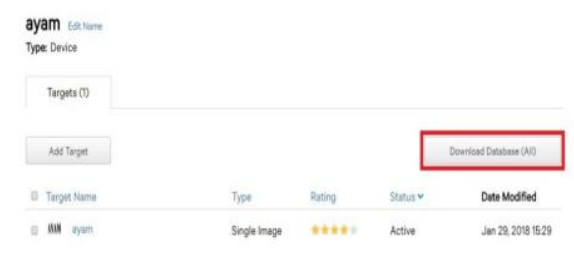

Gambar 3 Gambar yang berhasil di-upload

Setelah proses pembuatan package selesai, selanjutnya adalah mengunduh dengan mengklik Download Database, centang gambar marker yang ingin diunduh, kemudian pilih unity editor lalu klik download.

\section{Download Database}
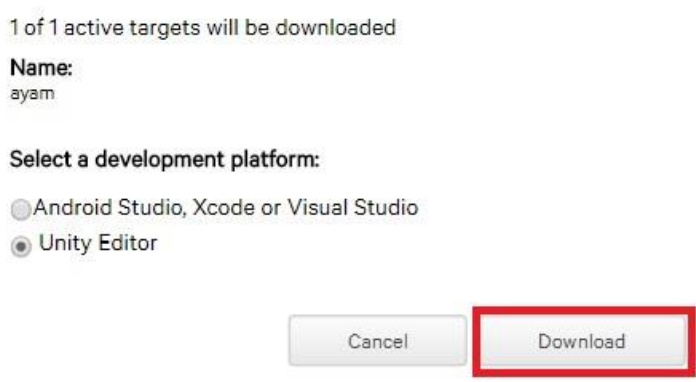

Gambar 4 Download marker

Setelah paket vuforia selesai diunduh, buka Software Unity 3D yang telah diinstall. Buat sebuah project baru, Beri nama project dan isikan project location sebagai lokasi penyimpanan file project, kemudian klik create.

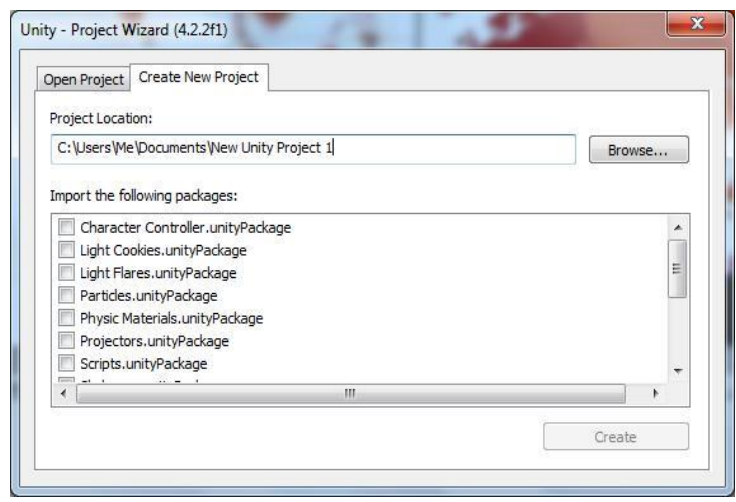

Gambar 5 Membuat project baru

Untuk membuat Scene Augmented Reality dibutuhkan vuforia package yang sudah didownload di langkah sebelumnya. Import vuforia package dengan cara pilih menu Assets, kemudian pilih Import Package, pilih Custom Package. 


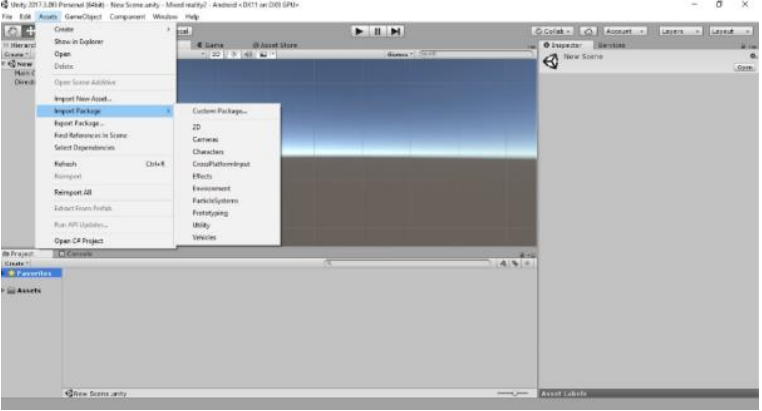

Gambar 6 Import custom package

Kemudian pilih package vuforia. Lalu akan muncul window Unity Importing Package, centang semua file dan pilih import.

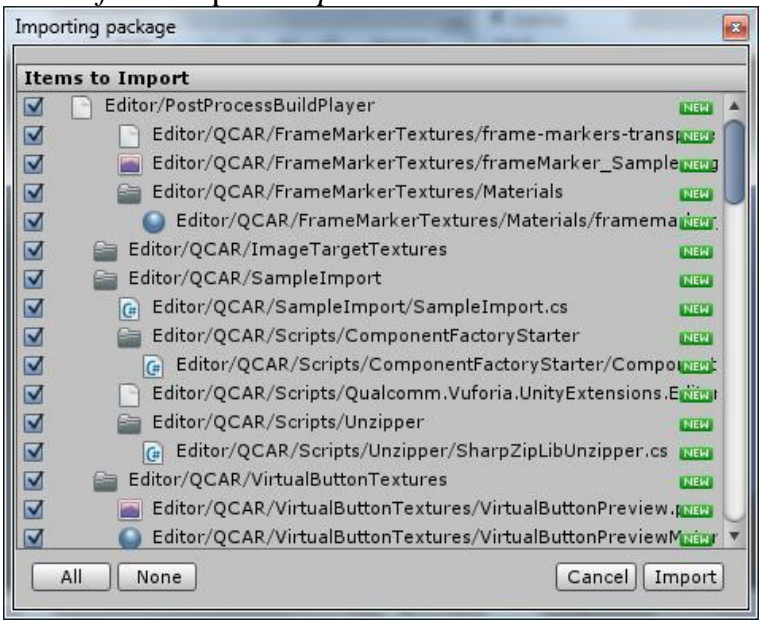

Gambar 7 Import vuforia package

Setelah itu import juga package marker yang telah di-upload dan diunduh dari web vuforia. Langkah-langkahnya sama dengan proses import vuforia package.

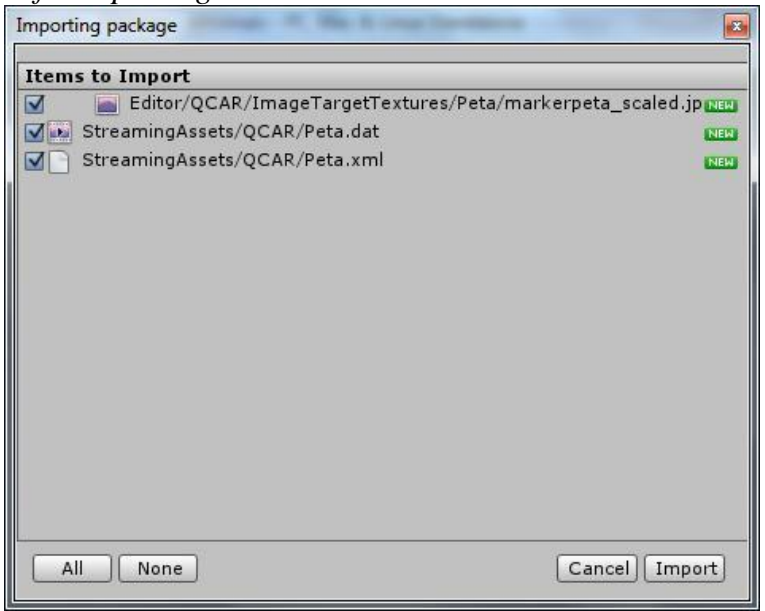

Gambar 8 Import marker package

Setelah kedua package berhasil di-import, drag AR Camera yang berada di dalam folder Qualcomm $>$ Prefabs ke Hierarchy. Kemudian drag juga Image Target yang berada di folder Prefabs. Untuk program Augmented Reality, Main Camera tidak dipergunakan dan digantikan oleh AR Camera, untuk itu hapus Main Camera pada bagian Hierarchy.

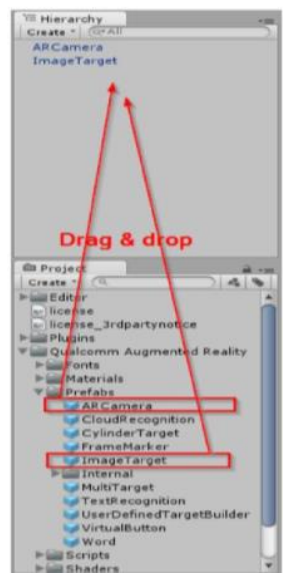

Gambar 9 Drag ARCamera dan ImageTarget

Selanjutnya dilakukan pengaturan pada $A R$ Camera dan Image target dengan cara mengklik $A R$ Camera yang berada pada tab Hierarchy. Pada tab Inspector, centang Load Data Set marker peta (sesuai nama package marker) dan centang Activate.

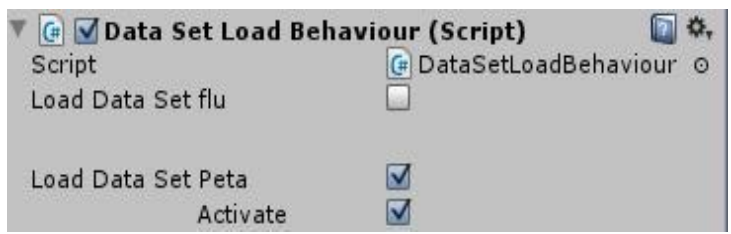

Gambar 10 Pengaturan AR Camera

Klik Image Target yang terdapat pada tab Hierarchy untuk melakukan pengaturan pada Image Target. Pada bagian Inspector. Lakukan konfigurasi seperti pada gambar di bawah ini. Setelah semua pengaturan selesai, simpan nama scene.

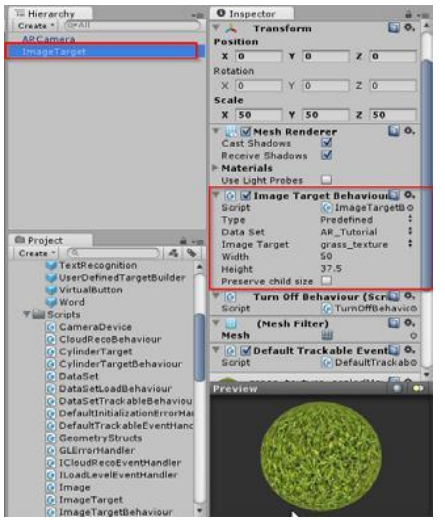

Gambar 11 Pengaturan ImageTarget

Pembuatan Menu Utama : Menu utama adalah halaman yang akan tampil paling awal ketika aplikasi dijalankan. Elemen-elemen yang terdapat pada halaman utama seperti background, tombol dan teks dibuat menggunakan Coreldraw. Setelah semua elemen selesai dibuat, elemen itu diletakkan pada 
Scene Menu dalam Unity. Pilih file > pilih new scene, kemudian Pilih gameobject > create other > custom

2. Plane. Import semua file gambar yang dibutuhkan kedalam folder Assets > Materials.

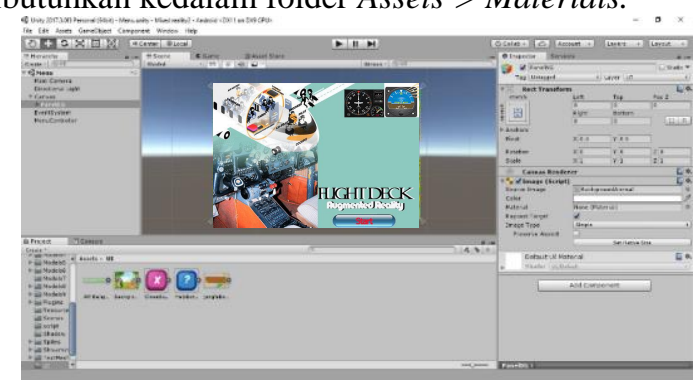

Gambar 12 Tampilan Halaman Utama

3. Pembuatan Tombol: Desain tombol juga dibuat menggunakan CorelDraw. Buat kembali beberapa plane dengan cara yang sama seperti pada langkah pembuatan menu, desain tombol yang sudah selesai, diletakkan pada plane. Agar tombol berfungsi, diberikan script yang diletakkan pada Main Camera. Untuk membuat script, klik kanan pada tab Assets, pilih create >C\# Script, dan modifikasi script.

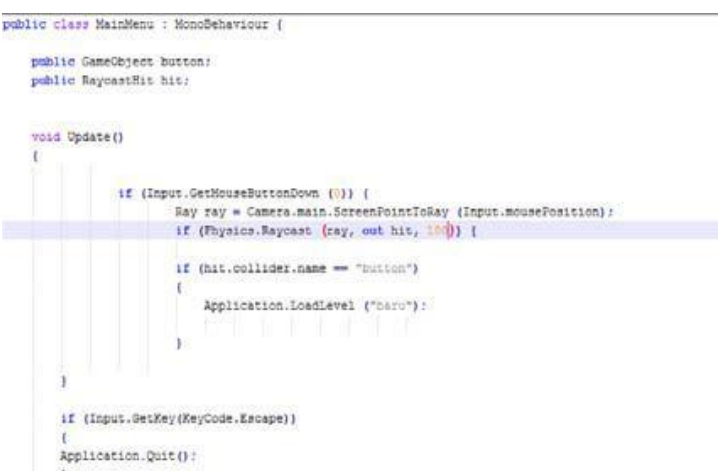

Gambar 13 Script untuk salah satu Tombol

4. Build Aplikasi: Tahap pembuatan aplikasi ini diakhiri dengan meng-compile program dan menjadikannya sebuah Android Package (APK). Langkah- langkah mem-build aplikasi adalah sebagai berikut:

5. Klik menu file dan pilih build settings Pilih platform android.

6. Drag seluruh scene yang telah dibuat.

Atur urutan scene yang telah dibuat. Scene yang paling pertama adalah scene menu, karena scene inilah yang akan ditampilkan pertama kali ketika aplikasi dijalankan.

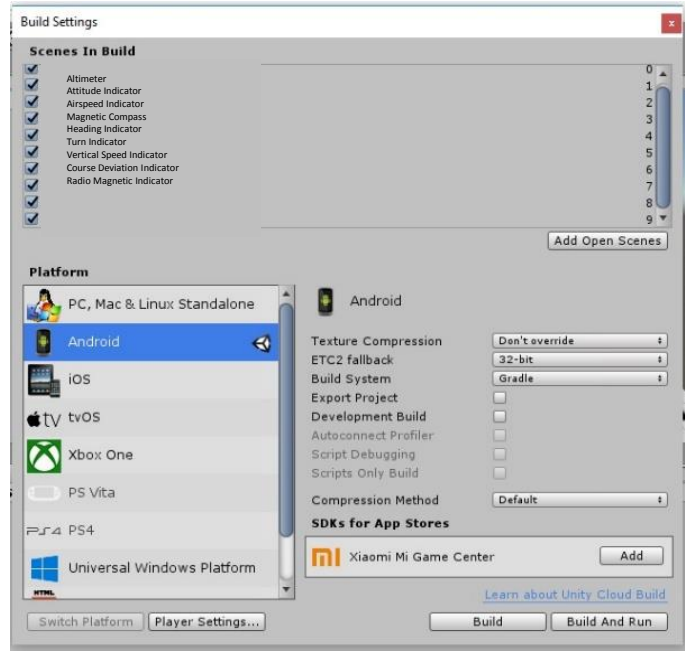

Gambar 14 Build Setting

Klik player setting untuk mengatur tampilan aplikasi dilayar Android, pilih auto rotation.

\begin{tabular}{||l|l|l|l|}
\hline Per-Platform Settings & \\
\hline Settings for Android & \\
Resolution and Presentation \\
Resolution \\
Default Orientation* \\
Allowed Orientations for Auto Rotation \\
Portrait \\
Portrait Upside Down \\
Landscape Right \\
Landscape Left \\
Status Bar \\
Status Bar Hidden \\
Use 32-bit Display Buffer* \\
Use 24-bit Depth Buffer* \\
Show Loading Indicator \\
* Shared setting between multiple platforms.
\end{tabular}

Gambar 15 Pengatur tampilan layar

7. Beri nama aplikasi yang akan diinginkan

8. Upload gambar ikon untuk ikon aplikasi Android

9. Klik build

10. Klik save, maka Unity akan melakukan proses build aplikasi

Setelah aplikasi selesai di -build, maka akan menghasilkan sebuah file android package (Apk). File apk ini merupakan file yang siap diinstall pada perangkat berbasis Android.

\section{HASIL DAN PEMBAHASAN}

Hasil

Pengujian harus dilakukan agar aplikasi yang dikembangkan berjalan dengan semestinya dan untuk meminimalisasi terjadinya kesalahan selama proses pembuatan. Metode yang digunakan untuk melakukan penelitian ini menggunakan metode black-box dengan memakai perangkat penguji berupa sebuah Smartphone Xiaomi Redmi 4X Android Version. Metode Pengujian Blackbox tidak secara langsung 
memeriksa sintaks dan struktur logis internal dari suatu perangkat lunak seperti pada Pengujian Whitebox, tetapi untuk mengetahui fungsi-fungsi yang diharapkan seperti output dihasilkan secara benar dari input, dan database diakses serta diupdate secara benar dan mengujinya apakah akan menjalankan fungsifungsi tersebut secara tepat.

Tabel 1 Pengujian Aplikasi

\begin{tabular}{cccc}
\hline No & Fungsi & $\begin{array}{c}\text { Output } \\
\text { Sistem }\end{array}$ & $\begin{array}{c}\text { Hasil Uji } \\
\text { Coba }\end{array}$ \\
\hline 1. & $\begin{array}{c}\text { Menampilkan AR } \\
\text { keterangan tabel } \\
\text { (dalam small caps), } \\
\text { keterangan }\end{array}$ & $\begin{array}{c}\text { Tampil AR } \\
\text { camera yang } \\
\text { digunakan } \\
\text { untuk men- }\end{array}$ & Berhasil \\
& gambar, item & scan marker & \\
referensi & gambar & \\
\hline 2. & Menampilkan & Muncul & Berhasil \\
& cockpit 2D alamat & objek & \\
& email penulisan & cockpit 3D & \\
& (dalam Courier), & & \\
& sel dalam tabel & & \\
\hline
\end{tabular}

Sebelum proses compile pastikan device Android sudah dapat dideteksi $a d b$ dan siap untuk debugging. Klik Build And Run, tunggu proses selesai, dan Android akan menjalankan aplikasi ini. Arahkan kamera ke marker dan objek tersebut akan muncul.

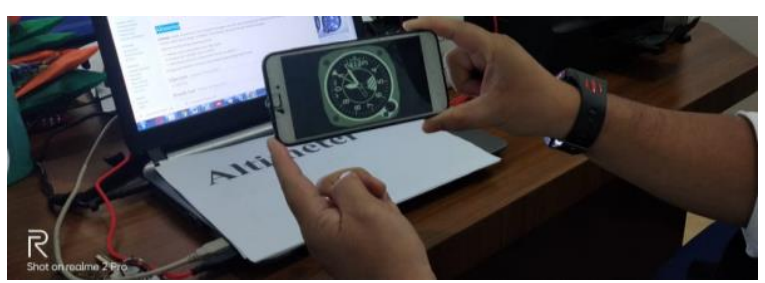

Gambar 16 Tampilan Objek Pada AR

Selain diuji coba pada perangkat Xiaomi Redmi $4 X$, aplikasi juga diujicobakan pada perangkat Android lain dengan spesifikasi yang berbeda, yaitu Oppo A71. Berikut tabel hasil pengujian aplikasi.

Tabel 2 Uji Coba Pada Berbagai Perangkat Mobile Android

\begin{tabular}{ccccc}
\hline Perangkat & Performa & $\begin{array}{c}\text { Kualitas } \\
\text { Tampilan }\end{array}$ & $\begin{array}{c}\text { Kualitas } \\
\text { Suara }\end{array}$ & Error \\
\cline { 3 - 4 } & & 3D & & \\
\hline Xiaomi & Sangat & Sangat & Sangat & Tidak \\
Redmi 4X & Baik & Baik & Baik & Ada \\
\hline Oppo & Sangat & Sangat & Sangat & Tidak \\
A71 & Baik & Baik & Baik & Ada
\end{tabular}

Pembahasan

Tampilan Menu Utama

Tampilan halaman awal beranda aplikasi yang terdiri dari

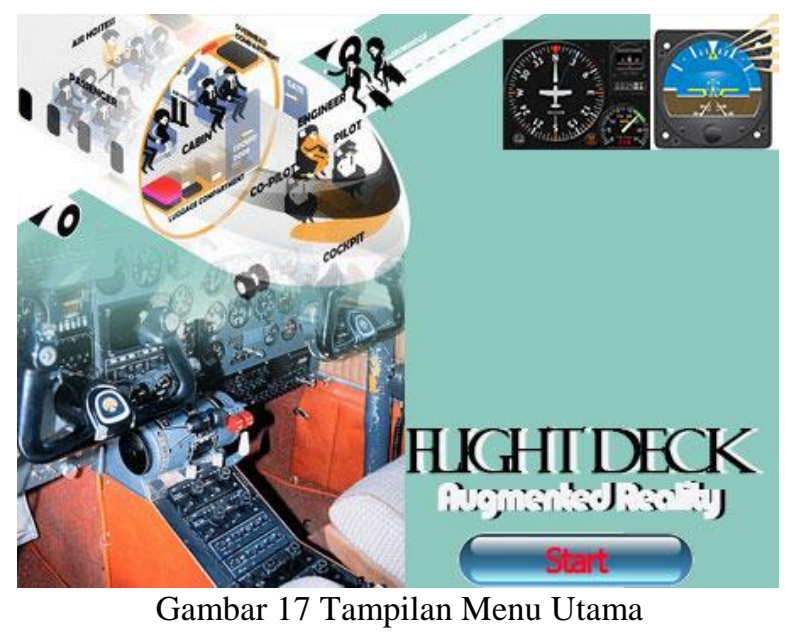

1. Tampilan Halaman Augmented Reality

Tampilan aplikasi pada sistem operasi Android tampilan anjing, beruang, dinasaurus, dan lain-lain. Pada saat kamera menangkap gambar nama di kertas maka akan memunculkan objek 3 dimensi di atas kertas, serta terdapat tombol kembali.

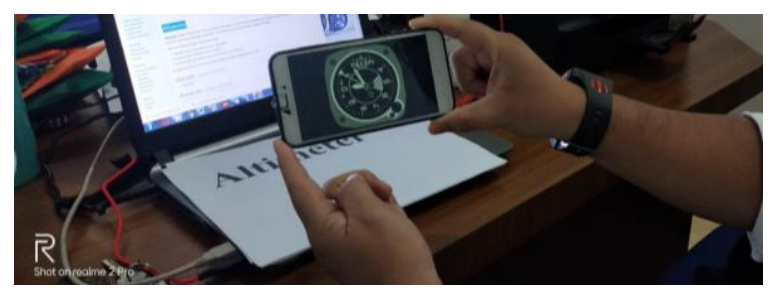

Gambar 18 Tampilan Objek Pada AR

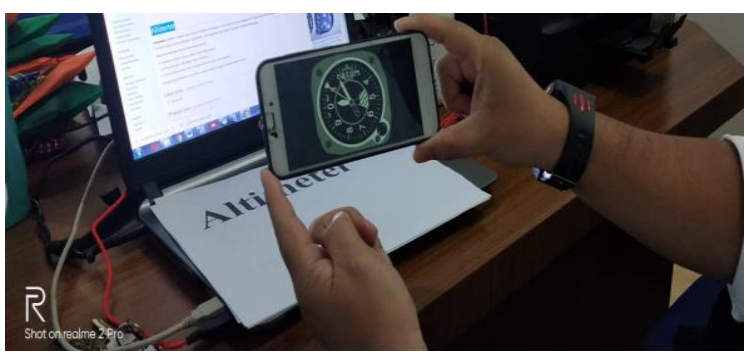

Gambar 19 Tampilan Augmented Reality Altimeter

Altimeter menunjukkan ketinggian dari pesawat yang dihitung dari atas permukaan laut (ASL/Above Sea Level). Altimeter adalah sebuah alat untuk mengukur ketinggian suatu titik dari permukaan laut. Biasanya alat ini digunakan untuk keperluan navigasi dalam penerbangan, pendakian, dan kegiatan yang berhubungan dengan ketinggian. 
Altimeter bekerja dengan beberapa prinsip:

a. Tekanan udara (yang paling umum digunakan)

b. Mangnet bumi (dengan sudut inclinasi)

c. Gelombang (ultra sonic maupun infra merah, dan lainnya). Penggunaan Altimeter umumnya selalu diikuti dengan penggunaan kompas.

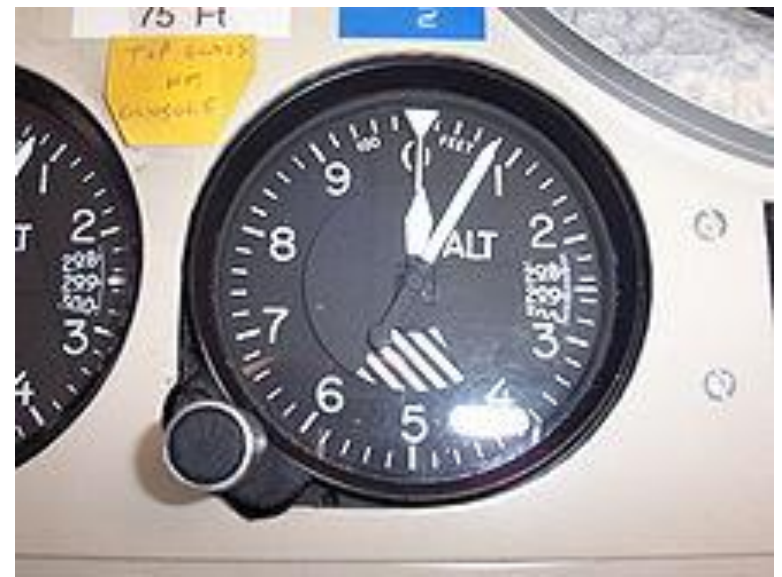

Gambar 20 Altimeter pesawat barometrik Tipe Kollsman digunakan di Amerika Utara

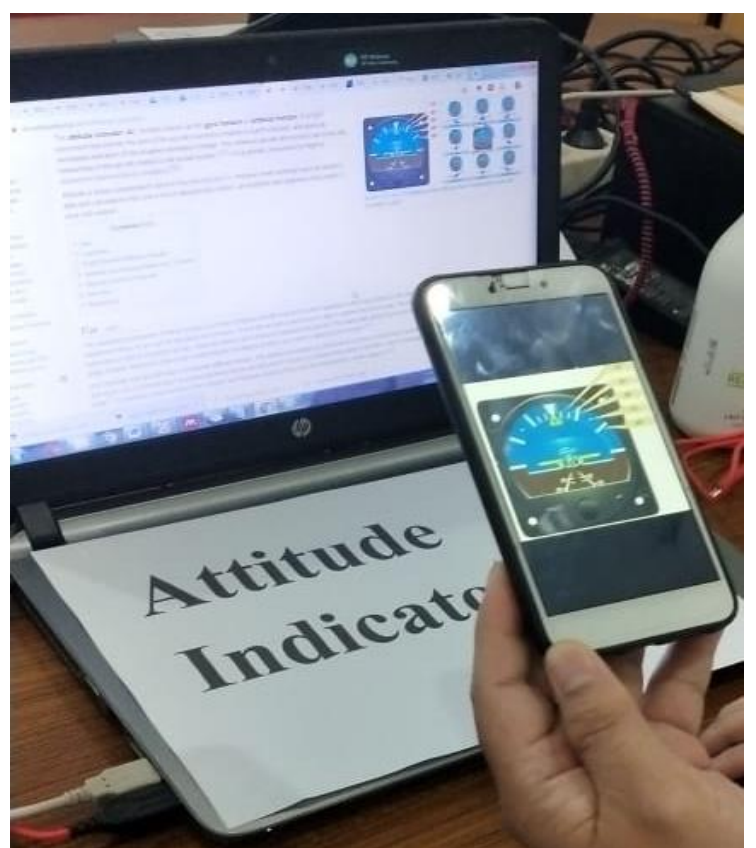

Gambar 21 Tampilan Augmented Reality Attitude Indicator

Attitude Indicator/Artificial Horizon menunjukkan letak pesawat terhadap garis horison. Instrumen ini dapat memberi informasi ketinggian nose pesawat terhadap garis horison saat sedang mengudara sehingga dapat menghindari peristiwa stall akibat nose yang terlalu tinggi atau terlalu rendah.

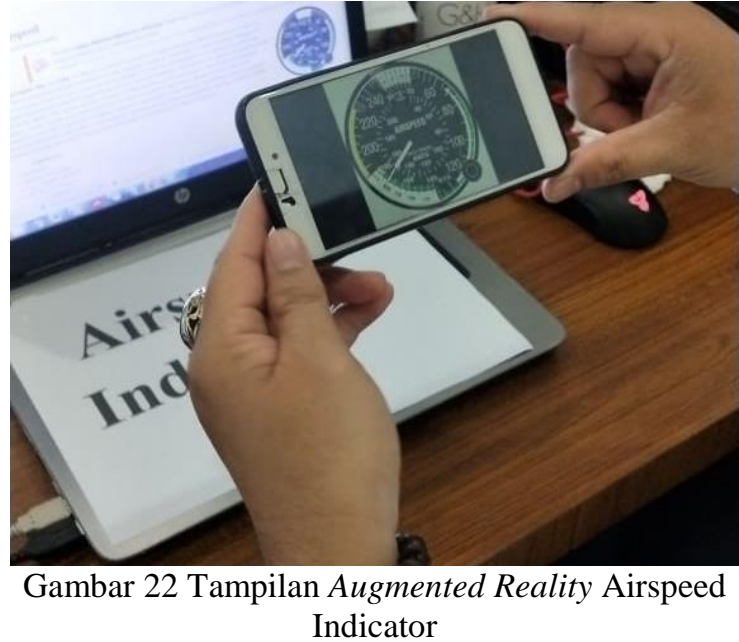

Airspeed Indicator menampilkan kecepatan pesawat (dalam knot) relatif terhadap keadaan udara di sekitar pesawat atau biasa disebut IAS (Indicated Airspeed). IAS merupakan kecepatan pesawat (TAS/True Airspeed) yang dipengaruhi oleh kepadatan udara (dipengaruhi oleh ketinggian, suhu, dan kelembaban) di sekitar pesawat.

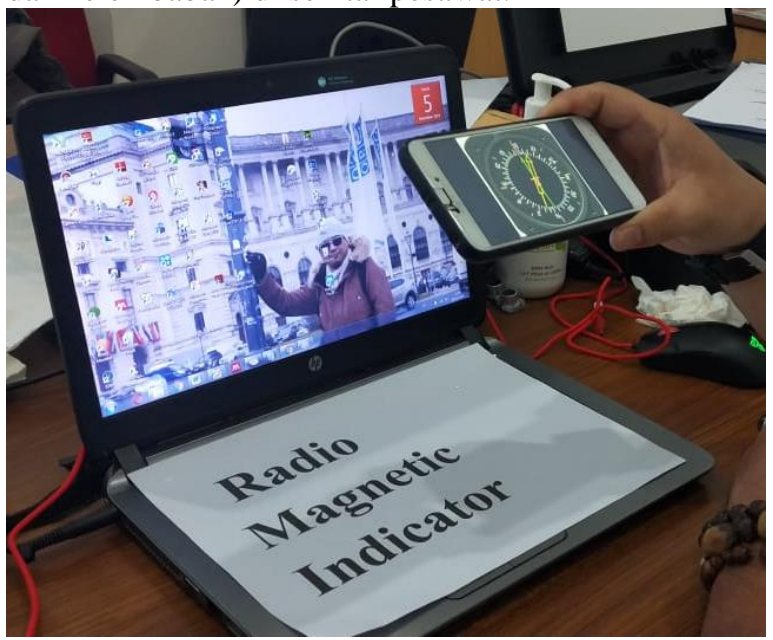

Gambar 23 Tampilan Augmented Reality Radio Magnetic Compass

Magnetic Compass, Kompas menampilkan arah maju pesawat (heading) relatif terhadap kutub utara bumi. 


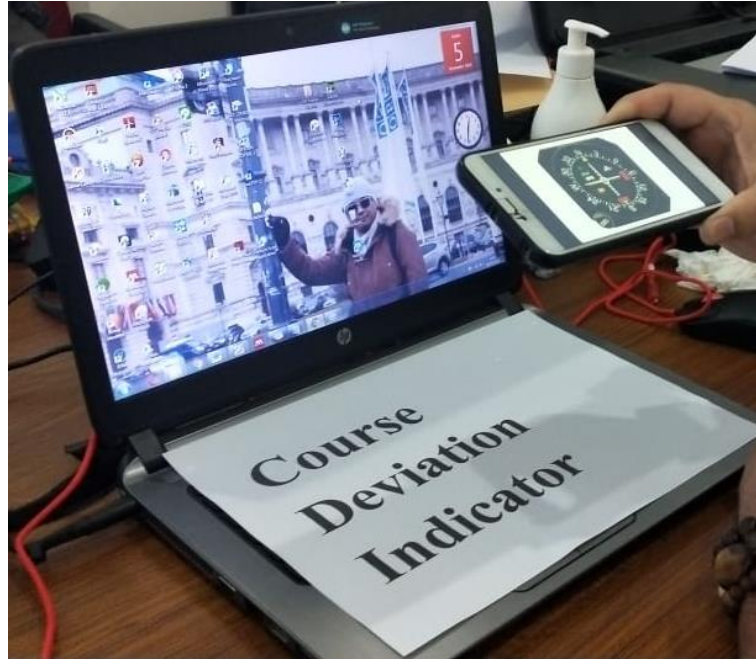

Gambar 24 Tampilan Augmented Reality Course Deviation Indicator

Course Deviation Indicator

Instrumen ini digunakan sebagai informasi navigasi yang mengindikasikan posisi pesawat berdasarkan jalur yang telah didaftarkan sebelumnya, juga bisa menunjukkan informasi VOR/ILS. Instrumen ini diintegrasikan dengan Heading Indicator yang dikenal dengan sebutan HSI (Horizontal Situation Indicator).

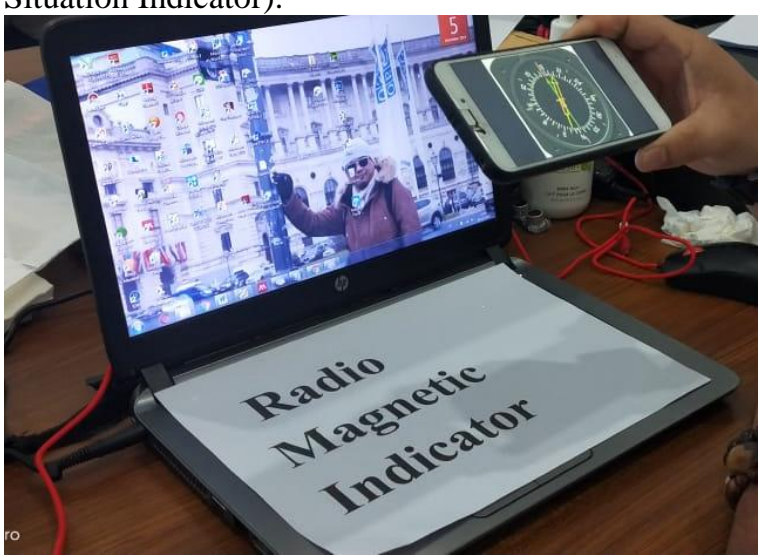

Gambar 25 Tampilan Augmented Reality Radio Magnetic Indicator

Radio Magnetic Indicator

Radio Magnetic Finder biasanya berpasangan dengan ADF (Automatic Direction Finder) yang berguna untuk penentuan posisi bandara menggunakan NDB (Non-directional Beacon).

Dari semua instrumen di atas, terdapat enam instrumen dasar yang diletakkan tepat di depan pilot yang disusun dalam bentuk $\mathrm{T}$ arrangement, yaitu: Airspeed Indicator, Attitude Indicator, VSI, Altimeter, Heading Indicator, dan Turn Indicator.

\section{KESIMPULAN}

Dari keseluruhan pembahasan yang telah dibahas diatas, maka peneliti dapat mengambil kesimpulan sebagai berikut:

1. Selain diuji coba pada perangkat mobile bersistem operasi Android (Xiaomi Redmi 4X), penerapan aplikasi Augmented Reality (AR) juga diujicobakan pada perangkat Android lain dengan spesifikasi yang berbeda dapat berjalan dengan baik dan beroperasi dengan lancar.

2. Penggunaan aplikasi Augmented Reality (AR) sebagai media pembelajaran pengenalan bentuk pesawat dan cockpit peswat terbang dirasa sangat efektif serta membantu proses belajar dan mengajar.

3. Penggunaan Vuforia SDK dan Unity 3D untuk pendeteksi marker dapat memberikan informasi pada pengguna dengan mengarahkan kamera AR pada marker nama bagian cockpit pesawat

Saran

Dalam pembuatan aplikasi ini masih terdapat kekurangan yang untuk selanjutnya bisa menjadi pertimbangan dalam pembuatan aplikasi selanjutnya. Adapun saran yang bisa disampaikan tentang aplikasi ini adalah:

1. Diharapkan kedepannya ada penelitian lanjutan terkait Komponen pesawat terbang dan sistem seperti: Struktur rangka pesawat; Flight Control Pesawat Terbang; Aerodinamika dan peralatan high-lift; Avionik dan sistem flight instrument; Kontrol mesin pesawat dan sistem bahan bakar; Roda pendaratan; dan Sistem lain

2. Perlu adanya penyempurnaan agar render pesawat terbang yang ditampilkan lebih detail.

Selain untuk Android bisa dikembangkan sebagai platform sensor [9] [10], kedepannya diharapkan dapat pula di akses melalui website atau menjadi sistem terintegrasi [11].

\section{DAFTAR PUSTAKA}

[1] Indriani, Riana., Sugiarto, B., dan Purwanto, A. "Pembuatan Augmented Reality Tentang Pengenalan Hewan Untuk Anak Usia Dini Berbasis Android Menggunakan Metode Image Tracking Vuforia". Seminar Nasional Teknologi Informasi dan Multimedia. STMIK AMIKOM Yogyakarta. pp.73-78. 2016.

[2] Irfansyah, J. "Media Pembelajaran Pengenalan Hewan Untuk Siswa Sekolah Dasar Menggunakan Augmented Reality Berbasis Android". Journal Information Engineering and Education Tecnology, Vol. 1, No. 01, pp.9-17. 2017. 
[3] Kementerian Pendidikan dan Kebudayaan. Benda, Hewan, dan Tanaman di Sekitarku. Jakarta: Kementerian Pendidikan dan Kebudayaan. 2013.

[4] Khair, R., Mustafid., dan Isnanto, R.R. "Sistem E-Career Perguruan Tinggi Berbasis Android (Start Up Application)". Jurnal Teknovasi, Vol. 03, No. 2, pp.8-28. 2016.

[5] Martono, K.T. "Pengaruh Struktur Aktiva, Profitabilitas dan Ukuran Perusahaan Terhadap Struktur Modal". Jurnal Ilmu dan Riset Manajemen, Vol. 4, No. 8, pp.1-16. 2011.

[6] Martono, K.T. "Augmented Reality Sebagai Metafora Baru dalam Teknologi Interaksi Manusia dan Komputer". Jurnal Sistem Komputer, Vol. 1, No. 2, pp.60-64. 2011.

[7] Pranata,B.A., Pamoedji, A.K., dan Sanjaya, R. Mudah Membuat Game dan Potensi Finansialnya dengan Unity 3D. Jakarta: PT Elex Media Komputindo. 2015.

[8] Zaman, Badru. Media Pembelajan Anak Usia Dini. Bandung: Universitas Pendidikan Indonesia. 2010.

[9] M. S. Hasibuan, Syafriwel, and I. Idris, "Intelligent LPG Gas Leak Detection Tool with SMS Notification," J. Phys. Conf. Ser., vol. 1424, no. 1, 2019.

[10] M. Zikri and R. Khair, "Rancang Bangun Monitoring Polusi Udara Berbasis Arduino," $J$. Teknovasi J. Tek. dan Inov., vol. 5, no. 1, pp. 27 38, 2018.

[11] I. Idris and Y. Delvika, "Analisis perancangan sistem informasi terintegrasi di lingkungan perguruan tinggi swasta di medan," J. Teknovasi J. Tek. dan Inov., vol. 1, no. 2, pp. 15-26, 2014. 